\title{
Стан та перспективи кадрового забезпечення ринку приватної медицини в Україні
}

\author{
(Представлено: д.держ.упр., проф. О.І. Пархоменко-Куцевіл)
}

\begin{abstract}
Завданням сучасної розвиненої держави є побудова ефективної моделі системи охорони здоров'я, досягнення найвищого рівня здоров'я населення та забезпечення розвитку здорової нації у найближчій перспективі. Наслідки виснажливого використання екологічних систем негативно впливають на здоров'я населення та призводять до зростання патологій, щзо в свою чергу призводить до значних сочіально-економічних збитків для суспільства. Недооціненим залишається внесок закладів ринку приватної медицини у фінансування медичної галузі в иілому. У статті наведено відмінності у діяльності державних та приватних медичних закладів охорони здоров'я. Варто зазначити і про суттєву недовіру до рівня професійних навиків, вмінь та досвіду вітчизняних лікарів, незважаючи на те, щчо одним із ключових факторів підвищення ефективності діяльності сфери охорони здоров'я є саме кадровий ресурс. Сьогодні у сфері охорони здоров'я світу праџюють 60 млн фахівців, однак попри изе, дефіџит медичних кадрів сягає 4,3 млн фахівців, у тому числі 2,4 млн лікарів. Попри дефіцит кадрів, проблемним залишається питання забезпеченості лікарями, які практикують у сільських регіонах. Незважаючи на цільове направлення значної частини випускників вищих медичних закладів у сільську місиевість, вакантними залишаються декілька тисяч посад лікарів в Україні. У статті охарактеризовано основні принципи, стан та перспективи отримання медичної освіти в Україні, окреслено особливості функціонування передових вищих медичних навчальних закладів 3 підготовки лікарів та провізорів, обтрунтовано необхідність з розвитком медичної науки змінювати ц̌ відповідні вимоги до професійних здібностей та компетентностей медичних фахівців. Зважаючи на це, цілком обтрунтованою є необхідність державного регулювання не тільки механізму підготовки фахівців для системи охорони здоров'я, але й цієєї галузі в цілому, в тому числі й ринку приватної медицини.
\end{abstract}

Ключові слова: охорона здоров'я; кадрове забезпечення ринку приватної медицини; здоров'я населення; державне регулювання медичних закладів.

Актуальність теми. Здоров'я населення є найвищою цінністю держави, а право на охорону здоров'я гарантує Конституція України. За роки незалежності українська система охорони здоров'я не набула статусу взірцевої та через постійні реформації не змогла вибудувати модель дієвих ринкових механізмів iii розвитку. Оскільки в сучасній вітчизняній системі охорони здоров'я частка приватного сектору значно розширюється, то об'єктивно посилюється й роль та значущість заходів щодо державного регулювання цього сектору через соціальну і політичну пріоритетності галузі, що визначило необхідність та актуальність дослідження.

Аналіз останніх досліджень та публікації, на які спирається автор. Дослідженнями проблем здоров'я населення як складової людського капіталу займалися такі вітчизняні науковці: О.Грішнова, І.Курило, Н.Левчук, Е.Лібанова, О.Макарова, С.Пирожков, Н.Рингач, А.Сердюк, В.Стешенко та ін. Окремим питанням дослідження здоров'я як окремого фактора економічного зростання присвячені праці таких науковців, як В.Геєць, І.Лук'яненко, І.Манцуров, В.Онікієнко, О.Осауленко, М.Скрипниченко, А.Філіпенко та інші.

Метою статті $є$ дослідження стану та особливостей кадрового забезпечення ринку приватної медицини в Україні та перспектив його подальшого реформування й розвитку через сучасні трансформації у країні.

Викладення основного матеріалу. Недооціненим залишається внесок закладів приватної медицини у фінансування медичної галузі в цілому. На думку окремих фахівців, «тіньова складова» ринку приватної медицини в Україні становить понад 2 млрд дол. США. Можна припустити, що за державної підтримки розвитку ринку приватної медицини та мінімізації перешкод розвитку галузі ці кошти перестануть бути «тіньовими» і держава у вигляді податків зможе доотримати близько 1 млрд гривень на рік, що створить сприятливі умови для фінансування системи охорони здоров'я в цілому.

За рекомендаціями ВООЗ та ЄС необхідним мінімумом бюджетних витрат на охорону здоров'я має бути 5 \% ВВП, в Україні ж ці витрати становлять лише $2,5 \%$.

(C) О.Д. Крикун, 2020 
Відмінності у діяльності державних та приватних медичних закладів очевидні для всіх суб’єктів галузі і зазначені в таблиці 1.

Відмінності у діяльності державних та приватних медичних закладів

\begin{tabular}{|c|c|c|}
\hline Характеристика & Приватний медичний заклад & Державний медичний заклад \\
\hline Ставлення до пацієнта & «Пацієнт - джерело доходів» & $\begin{array}{c}\text { «Пацієнт - додаткове } \\
\text { навантаження» }\end{array}$ \\
\hline $\begin{array}{c}\text { Відповідальність за результати } \\
\text { лікування }\end{array}$ & Висока & Низька \\
\hline $\begin{array}{c}\text { Здатність до інновацій та } \\
\text { сприйняття нового }\end{array}$ & Новаторство & Консерватизм \\
\hline $\begin{array}{c}\text { Дотримання стандартів } \\
\text { лікування та діагностики }\end{array}$ & Максимальне & Формальне \\
\hline Сприйняття інформації & $\begin{array}{c}\text { Прислухаються до корисної } \\
\text { інформації }\end{array}$ & Нівелюють інформацію \\
\hline Мотивація кар’єрного росту & $\begin{array}{c}\text { Пряма залежність кар’єрного } \\
\text { росту та винагороди за діяльність }\end{array}$ & $\begin{array}{c}\text { Відсутня мотивація до } \\
\text { кар'єрного росту }\end{array}$ \\
\hline Взаємозв’язок з колегами & Колеги - конкуренти & Колеги - друзі, знайомі \\
\hline Ставлення до медикаментів & Новаторсько-сучасне & Консервативне \\
\hline Характер праці лікаря & Творчий, продуктивний & Шаблонний \\
\hline Платоспроможність пацієнта & Висока & Низька \\
\hline $\begin{array}{c}\text { Відповідальність пацієнта } \\
\text { виконувати приписи лікарів }\end{array}$ & Висока & Низька \\
\hline
\end{tabular}

За даними опитування соціологічної групи «Рейтинг» [2] щодо рівня професіоналізму та компетентності лікарів в Україні були отримані такі результати (рис. 1).

\section{Як Ви оцінюєте рівень професіоналізму та компетентності лікарів в Україні?}

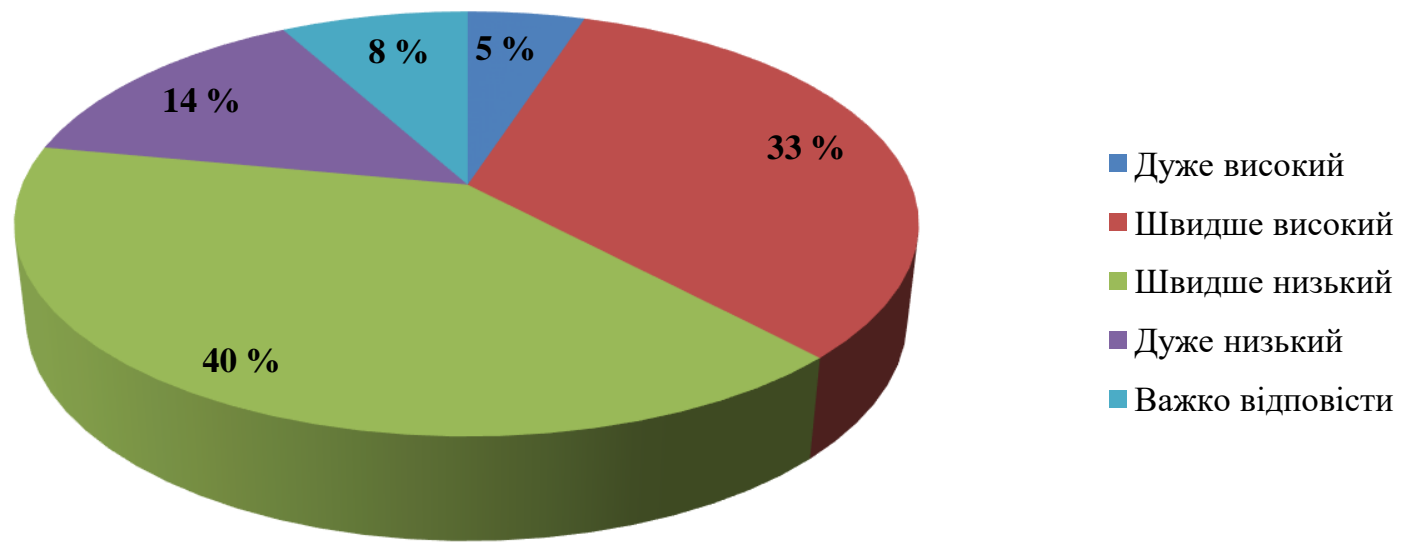

Рис. 1. Рівень професіоналізму та компетентності лікарів в Украӥні за даними опитування соціологічної групи «Рейтинг» [2]

Дані рисунка 1 свідчать про недовіру до рівня професійних навиків, вмінь та досвіду вітчизняних лікарів, незважаючи на те, що одним із ключових факторів підвищення ефективності діяльності сфери охорони здоров’я є кадровий ресурс.

Офіційні дані світової статистики сфери охорони здоров'я свідчать, що на 10 тис. населення у світі припадає в середньому 13 лікарів при достатньо суттєвих відмінностях між окремими регіонами та країнами. Так, наприклад, в Африканському регіоні забезпеченість лікарями на 10 тис. населення становить лише 2 лікаря, тоді як в Свропі - 32 [4]. 
За даними Державної служби статистики України забезпеченість лікарями з 1995 р. зменшилася в середньому на 3 лікаря і станом на кінець 2018 року становила 37,4 на 10 тис. населення порівняно 3 40,4 у 1995 році (рис.2).

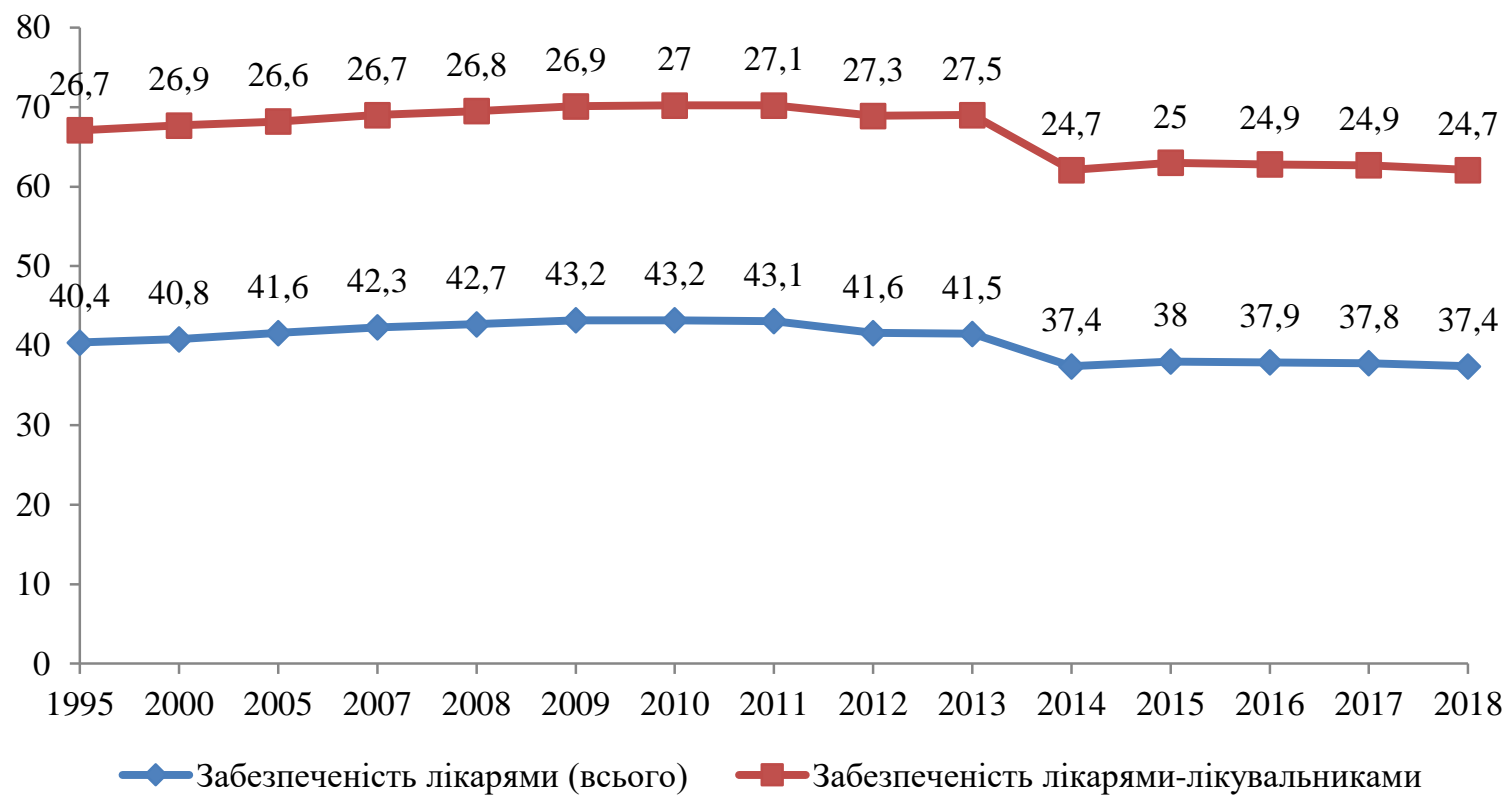

Рис. 2. Забезпеченість лікарями (фізичними особами) на 10 тис. населення [4]

Для прикладу, у Швеції та Фінляндії такий показник коливається в межах 33, у Франції та Німеччині 34, в Італії - 37, у Норвегії - 38, у Литві - 40, у Латвії - 31, у Великобританії - 23 та в Польщі - 20.

Структура лікарських кадрів за спеціальностями у 2018 році зображена на рисунку 3.

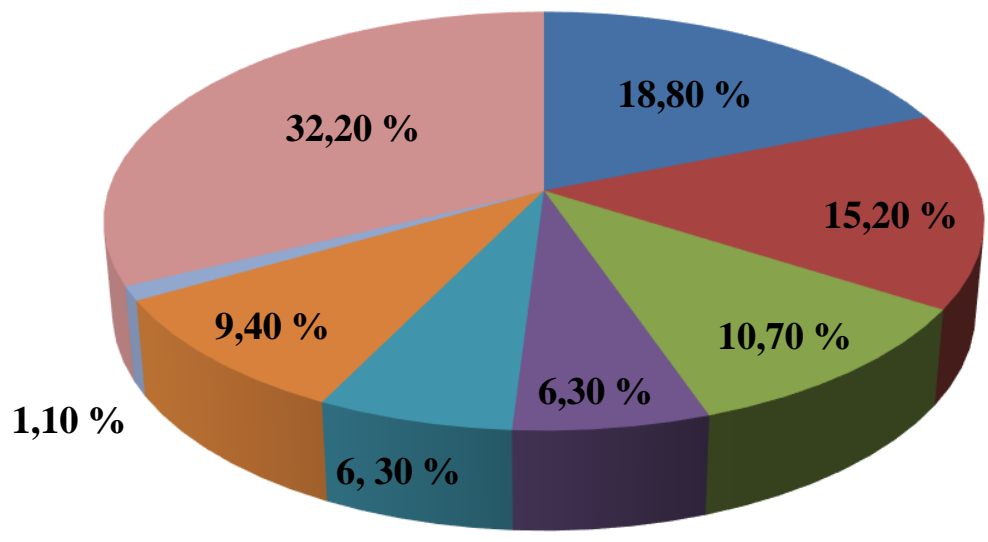

\section{- Терапевтична група}

— Хірургічна група

Стоматологи

- Педіатри та педіатринеонатологи

- Акушери-гінекологи

- Сімейні лікарі

Онкологи (вся група)

Інші

Рис. 3. Структура лікарських кадрів за спеціальностями у 2018 роичі [4]

Проблемним питанням на сьогодні залишається забезпеченість практикуючими лікарями у сільських регіонах. Незважаючи на направлення значної частини випускників вищих медичних закладів у сільську місцевість, вакантними залишаються декілька тисяч посад лікарів. 
Реформування та трансформація ринку приватної медицини потребує нових принципів отримання медичної освіти, адже основу будь-якої галузі становить у першу чергу підготовка висококваліфікованих фахівців.

Головними принципами отримання медичної освіти в Україні мають стати:

- використання медичною освітою передових новітніх технологій та інновацій медичної науки у процесі навчання; цілому;

- підвищення авторитетності отримання вищої медичної освіти та популяризація професії лікаря в нормами;

ототожнення кваліфікації лікаря $з$ фахівцем найвищого рівня та людиною 3 високими етичними

- визнання пацієнтів найвищою цінністю системи охорони здоров'я;

- перевага якісної складової у підготовці фахівців над кількісною; громаді;

одночасна автономія вищих медичних навчальних закладів та іiі підзвітність суспільству та

- $\quad$ трансформація медицини авторитетів у медицину досягнень.

В Україні сьогодні функціонує 14 вищих медичних навчальних закладів III-IV рівнів акредитації 3 підготовки лікарів та провізорів, серед них: Національний медичний університет, Вінницький національний медичний університет, Дніпропетровська медична академія, Донецький національний медичний університет, Запорізький медичний університет, Івано-Франківський національний медичний університет.

У вищих медичних (фармацевтичних) навчальних закладах III-IV рівнів акредитації навчається 64,9 тис. студентів, 3 яких 25,0 тис. - за державним замовленням та 39,9 тис. - за кошти юридичних та фізичних осіб. Всього за медичними спеціальностями сьогодні навчається близько 150 тис. осіб, які $\epsilon$ громадянами України, більшість з яких у вищих медичних закладах, що підпорядковуються Міністерству охорони здоров'я України. Окрім цього, станом на 2018-2019 навчальний рік на українських університетських теренах здобували медичну освіту близько 23 тис. студентів, що $є$ іноземними громадянами. У 2018 році випущено 11,5 тис. спеціалістів (2017 рік - 10,3 тис.) (рис. 4).

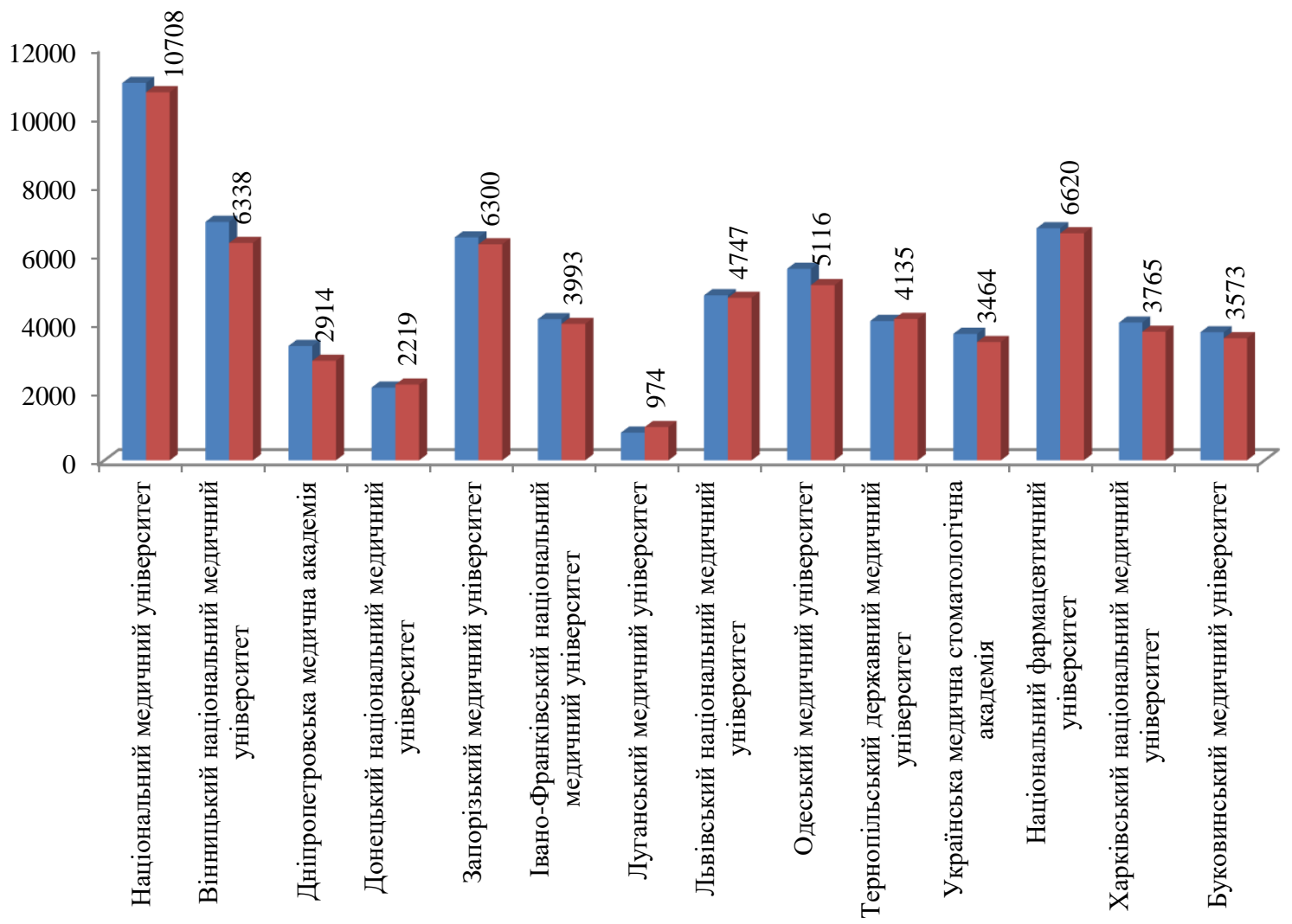

$\square 2017 \square 2018$

Рис. 4. Кількість студентів вищих медичних навчальних закладів III-IV рівнів акредитації з підготовки лікарів та провізорів [4] 
Найвищий показник кількості студентів в Україні має Національний медичний університет (10977 студентів у 2017 році та 10708 - у 2018), Вінницький національний медичний університет (6950 чол. у 2017 році та 6338 чол. - у 2018), Національний фармацевтичний університет (6765 чол. у 2017 році та 6620 - у 2018) та Запорізький медичний університет (6499 чол. у 2017 році та 6300 - у 2018).

Щодо спеціальностей, за якими студенти вищих медичних навчальних закладів III-IV рівнів акредитації здобували освіту у 2018 році, то «фаворитами» тут були такі напрями: «Медицина» 18011 чол., «Лікувальна справа» - 15898 чол. та «Фармація» -17685 чол. (рис. 5).

\section{2}

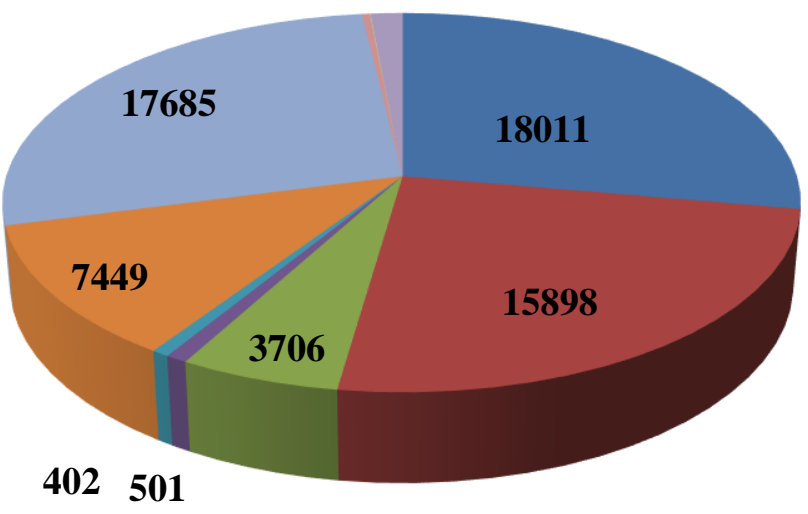

- Медицина

- Лікувальна справа

Педіатрія

• Медико- профілактична

справа

- Медична психологія

птоматологія

- Фармація

- Клінічна фармація

Ерготерапія

- Інші спеціальності

Рис. 5. Розподіл студентів вищих медичних навчальних закладів III-IV рівнів акредитації за спеціальностями у 2018 роиі, чол. [4]

Особливістю отримання медичної освіти в Україні $є$ те, що повний термін навчання для здобуття кваліфікації лікаря становить близько 6-9 років, з них 5-6 років - навчання у вищому медичному навчальному закладі та 1-3 роки - навчання в інтернатурі та магістратурі. Водночас у Сполучених Штатах Америки професію лікаря здобути менше, ніж за 11 років не вдасться, а повний термін навчання становить там від 11 до 14 років. У США 3-4 роки студент-медик має вчитися у медичному коледжі, ще 4 роки - у медичній школі, далі 3-5 років - в резидентурі (в тому числі 1 рік в інтернатурі та 2-4 роки триває факультативне навчання). В Ізраїлі повний строк навчання та здобуття вищої медичної освіти становить 12 років, у Німеччині - 11-12 років, у Франції - 8-11 років. Можливо, й в Україні загальний термін навчання невдовзі може змінитися та стане аналогічним світовому досвіду.

У 2018 році у вищих медичних навчальних закладах I-II рівнів акредитації навчалося 56,8 тис. осіб (у 2017 році - 61,2 тис.). Випущено молодших спеціалістів з медичною освітою у 2018 році - 17,7 тис. (у 2017 році - 19,0 тис.). Кількість студентів у вищих медичних навчальних закладах I-II рівнів акредитації у розрізі адміністративно-територіальних одиниць у 2017-2018 роках наведено у таблиці 2.

3 метою реформування середньої медичної ланки в Україні було створено Центр розвитку медсестринства, основною метою діяльності якого є захист прав та інтересів медсестер та медбратів, підвищення престижності професії, розвитку нової пацієнто-орієнтованої моделі медсестринства тощо. У підготовці фахівців з напряму «Медсестринство» середньої медичної ланки також передбачено низку змін, в тому числі збільшення фактичної практичної підготовки на додипломному етапі.

Найближчим часом планується запровадження вищої медичної освіти та можливість здобуття наукового ступеню за спеціальністю «Медсестринство». Роль медичної сестри (медичного брата) в наданні професійної допомоги планується збільшити та відповідно розширити їх повноваження, а також надати законно обгрунтовану можливість отримати сертифікат, наявність якого забезпечить розширення кола їх компетенцій та підвищення заробітної плати медичних працівників.

У Міністерстві охорони здоров'я зауважують, що відмінною рисою української медицини та медицини деяких пострадянських країн є зарахування професії медсестри та медбрата до середньої медичної ланки, яка необов'язково передбачає наявність вищої освіти. Насправді ж, 3 розвитком медичної науки відповідно мають змінюватися й вимоги до професійних здібностей та компетентностей медичних фахівців. 
Кількість студентів у вищих медичних навчальних закладах I-II рівнів акредитації у розрізі адміністративно-територіальних одиниць у 2017-2018 роках [4]

\begin{tabular}{|c|c|c|}
\hline \multirow{2}{*}{ Область } & \multicolumn{2}{|c|}{ Всього навчається } \\
\hline & 2017 рік & 2018 рік \\
\hline 1 & 2 & 3 \\
\hline Автономна Республіка Крим & - & - \\
\hline Вінницька & 2761 & 2493 \\
\hline Волинська & 1868 & 1663 \\
\hline Дніпропетровська & 4162 & 4073 \\
\hline Донецька & 1256 & 1282 \\
\hline Житомирська & 3688 & 3398 \\
\hline Закарпатська & 1314 & 1181 \\
\hline Запорізька & 2669 & 2447 \\
\hline Івано-Франківська & 2950 & 2694 \\
\hline Київська & 1043 & 865 \\
\hline Кіровоградська & 1345 & 1233 \\
\hline Луганська & 805 & 773 \\
\hline Львівська & 2878 & 2610 \\
\hline Миколаївська & 1748 & 1659 \\
\hline Одеська & 2913 & 2824 \\
\hline Полтавська & 2633 & 2463 \\
\hline Рівненська & 2740 & 2464 \\
\hline Сумська & 1831 & 1796 \\
\hline Тернопільська & 2338 & 2191 \\
\hline Харківська & 5472 & 5036 \\
\hline Херсонська & 2142 & 1990 \\
\hline Хмельницька & 2665 & 2354 \\
\hline Черкаська & 2527 & 2416 \\
\hline Чернівецька & 1994 & 1688 \\
\hline Чернігівська & 1812 & 1714 \\
\hline м. Київ & 3597 & 3472 \\
\hline м. Севастополь & - & - \\
\hline Всього & 61151 & 56779 \\
\hline
\end{tabular}

Аналіз забезпеченості кадрової складової системи охорони здоров’я засвідчив збереження сталих тенденцій скорочення кількості лікарів та персоналу середньої медичної ланки. Це відбувається на тлі зменшення чисельності населення і відповідним чином відображається на динаміці забезпеченості лікарями на 10 тис. населення.

Крім того, медична галузь займає одне з провідних місць в українській науці. Отримання наукових ступенів відкривають більш широкі можливості подальшого працевлаштування та кар'єрного зростання. У період 1993-2020 рр. дисертації на здобуття наукового ступеня доктора медичних або фармацевтичних наук становили близько 15 \% від загальної кількості захищених в Україні. Протягом 2018-2020 років (дані станом на 20 квітня 2020 року) видано 1227 дипломів кандидата медичних наук та 236 дипломів доктора медичних наук. Медична галузь входить до п’ятірки лідируючих галузей за кількістю захищених дисертацій як для здобуття наукового ступеня доктора наук, так і для здобуття наукового ступеня кандидата наук (рис. 6.).

Крім того, у 2018 році із 18419 аспірантів в Україні у галузі знань «Охорона здоров'я» було зареєстровано 1301 чол., а кількість осіб, зарахованих до аспірантури в цій же галузі знань у 2018 році, 
становила 495 чол. Серед загальної кількості докторантів (1049 чол.) в галузі знань «Охорона здоров’я» зареєстровано 28 чол., а кількість осіб, зарахованих до докторантури у 2018 році, - 17 чол. [6].

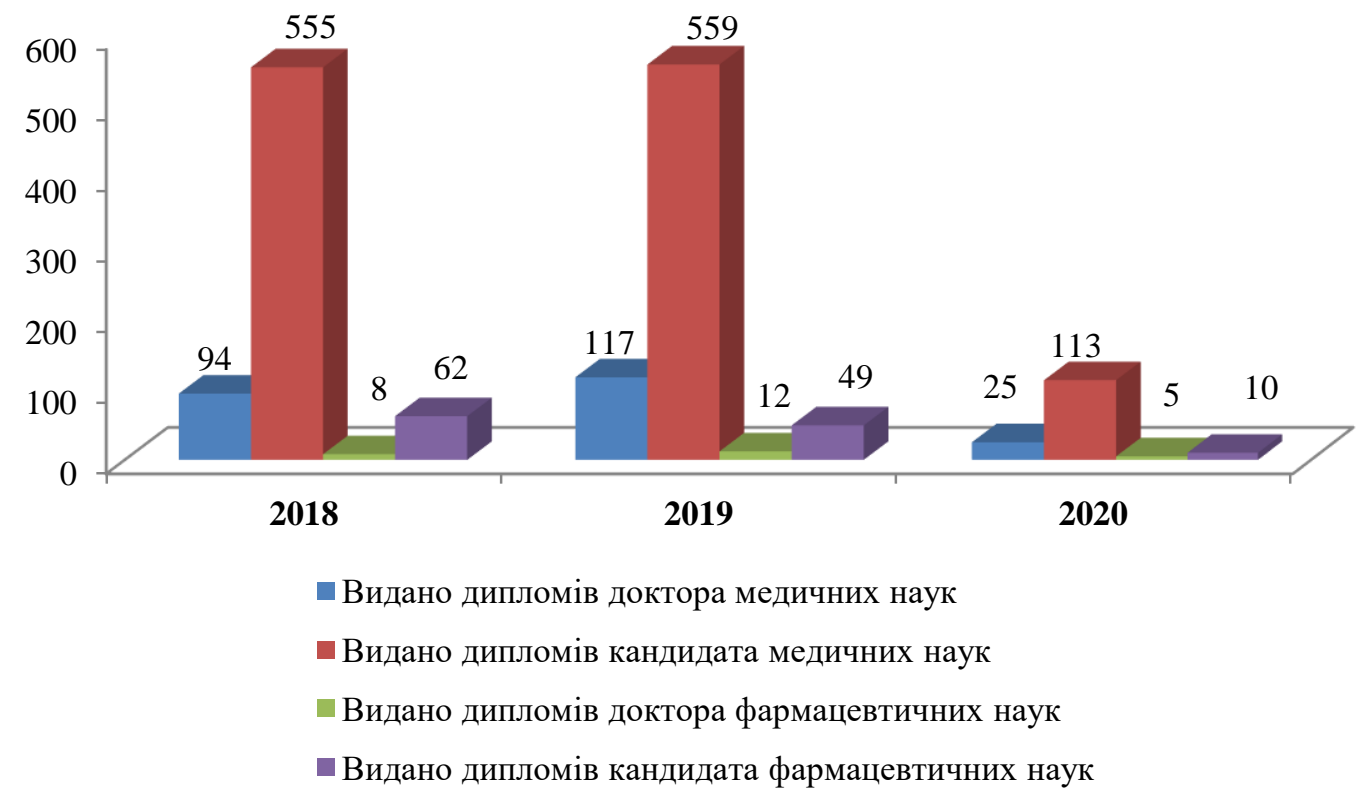

Рис. 6. Кількість виданих дипломів кандидата та доктора наук у 2018-2020 роках [6]

Проведений аналіз дав змогу виокремити низку проблем кадрових ресурсів сфери охорони здоров'я, серед них:

- нераціональний розподіл професійних медичних кадрів;

- дисбаланс, брак та подекуди низька якість професійних вмінь, знань та навичок; Україні;

- підвищений рівень мобільності та міграції кадрів через низький рівень заробітної плати в

- незадовільний рівень оснащеності медичних закладів, що знижує якість наданих послуг;

- невідповідність тактичних та стратегічних напрямів розвитку медичної галузі та політики у сфері охорони здоров'я;

- недосконалість нормативно-правового регулювання галузі;

- недостатність знань для формування політики та ухвалення суспільно-важливих рішень у сфері охорони здоров'я.

Висновки та перспективи подальших досліджень. Покращення здоров'я та благополуччя населення має стати пріоритетом державної політики у сфері ринку приватної медицини та політики системи охорони здоров’я в цілому. Окремі адміністративно-територіальні одиниці, регіони та держава в цілому цілком вірогідно можуть ставити спільні цілі та разом здійснювати інвестиції як у сектор системи охорони здоров'я, так і в інші сектори, що істотно впливають на розвиток здоров'я населення. Пріоритетними тут є освіта, соціальний захист, умови праці та відпочинку, а також зниження рівня бідності населення. Підходи, що можуть використовуватися, мають насамперед враховувати в себе підвищення стійкості громад до негативного впливу навколишнього середовища, залучення окремих громадян в життя суспільства в цілому та зміцнення соціальної відповідальності та солідарності, а також сприяння розвитку ресурсів благополуччя, тобто активізацію сильних сторін і переваг окремих людей та співтовариств, що можуть захищати та зміцнювати здоров’я населення. Ці заходи мають бути постійними, систематичними та обгрунтованими.

\section{Список використаної літератури:}

1. Куплю здоров’я: ТОП приватних медичних закладів України [Електронний ресурс]. - Режим доступу : https://youcontrol.com.ua/data-research/kupliu-zdorovia-top-pryvatnykh-medychnykh-zakladiv-ukrayiny/.

2. Сайт соціологічної групи «Рейтинг» [Електронний ресурс]. - Режим доступу : http://ratinggroup.ua/.

3. Диверсифікація джерел фінансування охорони здоров'я [Електронний ресурс]. - Режим доступу : https://niss.gov.ua/doslidzhennya/socialna-politika/diversifikaciya-dzherel-finansuvannya-okhoroni-zdorovya.

4. Медичні кадри та мережа закладів охорони здоров'я системи МОЗ України за 2017-2018 роки : довідник. Центр медичної статистики МОЗ України, 2019. - 66 с. 
5. Шиак Г.В. Аналіз забезпечення галузі охорони здоров'я лікарями / Г.В. Шпак, I.I. Волинкін // Україна. Здоров’я нації. - 2011. - № 2 (18). - С. 121-125.

6. Динаміка захисту дисертацій у 2018-2020 pp. [Електронний ресурс]. - Режим доступу : http://aphd.ua/dynamika-zakhystu-dysertatsii-u-2018-2020-rr-/.

7. Офіційний сайт Державної служби статистики України [Електронний ресурс]. - Режим доступу : http://www.ukrstat.gov.ua/.

8. Урсол Г.М. Приватний сектор системи охорони здоров'я - активний резерв підвищення доступності та якості надання медичної допомоги: досвід Кіровоградської області / Г.М. Урсол, О.А. Скрипник, О.М. Василенко // Буковинський медичний вісник. - 2014. - Т. 18, № 4 (72). - С. 177-181.

\section{References:}

1. Kuplju zdorov'ja: TOP pryvatnyh medychnyh zakladiv Ukrai'ny, [Online], available at: https://youcontrol.com.ua/data-research/kupliu-zdorovia-top-pryvatnykh-medychnykh-zakladiv-ukrayiny/

2. Sajt sociologichnoi' grupy «Rejtyng», [Online], available at: http://ratinggroup.ua/

3. Dyversyfikacija dzherel finansuvannja ohorony zdorov'ja, [Online], available at: https://niss.gov.ua/doslidzhennya/socialna-politika/diversifikaciya-dzherel-finansuvannya-okhoroni-zdorovya

4. MOZ Ukrai'ny (2019), Medychni kadry ta merezha zakladiv ohorony zdorov'ja systemy MOZ Ukrai'ny za 20172018 roky, dovidnyk, Centr medychnoi' statystyky MOZ Ukrai'ny, 66 p.

5. Shpak, G.V. and Volynkin, I.I. (2011), «Analiz zabezpechennja galuzi ohorony zdorov'ja likarjamy», Ukrai'na. Zdorov'ja nacii', No. 2 (18), pp. 121-125.

6. Dynamika zahystu dysertacij u 2018-2020 rr., [Online], available at: http://aphd.ua/dynamika-zakhystu-dysertatsiiu-2018-2020-rr-/

7. Oficijnyj sajt Derzhavnoi' sluzhby statystyky Ukrai'ny, [Online], available at: http://www.ukrstat.gov.ua/

8. Ursol, G.M., Skrypnyk, O.A. and Vasylenko, O.M. (2014), «Pryvatnyj sektor systemy ohorony zdorov'ja aktyvnyj rezerv pidvyshhennja dostupnosti ta jakosti nadannja medychnoi' dopomogy: dosvid Kirovograds'koi' oblasti», Bukovyns'kyj medychnyj visnyk, Vol. 18, No. 4 (72), pp. 177-181.

Крикун Олена Дем'янівна - аспірантка кафедри публічного адміністрування Міжрегіональної академії управління персоналом.

Наукові інтереси:

- $\quad$ державне управління у сфері охорони здоров’я.

Стаття надійшла до редакції 28.04.2020. 